\title{
Anaerobic digestion of mixed silage of waterweed biomass and wheat straw in a long-term semi-continuous biogas production process
}

\author{
Aline Bauer ${ }^{1}$, Lucie Moeller ${ }^{1}$, Harald Wedwitschka ${ }^{2}$, Walter Stinner ${ }^{2}$ and Andreas Zehnsdorf ${ }^{* *}$
}

\begin{abstract}
Background: As part of the maintenance of lakes and rivers, large quantities of aquatic biomass are produced every year. Neophytes, such as Elodea nuttallii, compete with native species and cause a disturbance to the ecosystem, which can manifest itself in the form of eutrophication. Aquatic macrophytes are not in competition with the production of food and animal feed and thus can be used in anaerobic digestion plants to replace a fraction of commonly used renewables such as maize or grass silage. Mixed silage of Elodea biomass with wheat straw was recently developed to allow for the conservation of mowed aquatic biomass. In this paper, the digestibility of this silage was tested in a long-term semi-continuous fermentation experiment with a duration of 212 days.
\end{abstract}

Methods: A continous-stirred tank reactor with a working volume of $31 \mathrm{~L}$ was used for the semi-continuous fermentation experiment. The substrate Elodea-straw silage was supplied to the fermenter once a day. The samples of digestates were analyzed directly after sampling twice a week for total solids, volatile solids, VFATAC, $\mathrm{NH}_{4}-\mathrm{N}$, acetate, propionate, butyrate, and water-solutle elements. The biogas composition was determined by means of gas chromatograph once a week.

Results: The results show that mono-fermentation of Elodea straw silage was stable for a period of at least 6 months. A stable anaerobic digestion process was achieved at an organic loading rate (OLR) of up to $2 \mathrm{gvs} /\left(\mathrm{L}^{*} \mathrm{~d}\right)$, when the highest specific biogas yield of $642 \mathrm{mLN} /\left(g_{v s}{ }^{*} d\right)$ was reached. The process turned unstable when the OLR was increased to $3 \mathrm{gvs} /\left(L^{*} \mathrm{~d}\right)$ due to the accumulation of volatile fatty acids. A nitrogen source, urea, was added in order to support the anaerobic digestion process. No addition of any further supplements was needed. Throughout the whole experiment, the specific biogas yield reached $647 \pm 71 \mathrm{~mL} /\left(\mathrm{gvs}^{*} \mathrm{~d}\right)$ with a mean methane content of $51 \%$.

Conclusions: The results of this semi-continuous fermentation experiment confirm the possibility of using Elodea straw silage as a mono-substrate in the anaerobic digestion process for the production of biogas being the aim of this Short Communication.

Keywords: Elodea nuttallii, Neophyte, Aquatic macrophytes, Aquatic biomass, Biogas yield, Wheat straw, Silage, Anaerobic digestion, Semi-continuous fermentation

\footnotetext{
*Correspondence: andreas.zehnsdorf@ufz.de

${ }^{1}$ Helmholtz Centre for Environmental Research-UFZ, Centre for

Environmental Biotechnology, Permoserstrasse 15, 04318 Leipzig, Germany

Full list of author information is available at the end of the article
} 


\section{Background}

Aquatic macrophytes are plants that grow in water and have adapted to their water habitat. In addition to submerged and immersed plants such as waterweed, there are also marsh plants (helophytes) such as reeds growing in bodies of water. Aquatic plants are valuable inhabitants of the biotopes of flowing and standing waters in Germany. They are habitats for small water animals including fry, they serve as feed for aquatic herbivores, and they release oxygen into the water and take up nutrients. Furthermore, they provide competition to algae growth. However, if overgrowth occurs, aquatic macrophytes can create problems in the operational use of waterways that can have serious economic consequences for the operators of these bodies of water. A particular role is played by invasive neophytes such as waterweed, some parrot's feather species, and duckweed. The strong covering of vegetation inhibits ship and boat traffic in flowing and standing waters. The slightly fragile plants that remain after the vegetation period can accumulate and then negatively influence flood protection, water engineering works, and the operation of hydroelectric power stations. There are also problems in the use of the waters as recreation areas-e.g., bathing facilities can become severely impaired. The proliferation of these plants can influence standing and flowing waters in a long-term manner.

To get an idea of the range of the problem, the following example should be mentioned: narrow-leaved waterweed (Elodea nuttallii) has been proliferating at an enormous rate in German waterways and lakes in recent decades. In 2004 , about 26,000 metric tons of fresh plant material was produced in the Goitzsche lake $\left(13 \mathrm{~km}^{2}\right)$ in Saxony-Anhalt, Germany [1].

In order to solve the abovementioned problems, various costly measures are implemented for the removal and reduction of macrophytes in waters. Most often, the aquatic macrophytes are mowed using mowing boats [2] and disposed of without further use. Due to this reason, costs for water operators arise. In 2008, the total cost of weed control in watercourses in Germany was estimated at about 100 million euros per year [3]. Hussner et al. [4] also reported recently that the costs for combating invasive water plants in Europe were several million euros per year. It must be assumed that these costs will continue to increase, with the inclusion of the standing bodies of water and the gradual spread of neophytes.

The water plants are not very suitable for composting because of their high water content. However, this aquatic biomass is an attractive substrate for biogas production as it does not compete with agricultural land use for food and feed production and does not need any agricultural land or processing (fertilizing, etc.) as the water plants grow in the natural aquatic environment.
The mowing of aquatic macrophytes in waters subject to overgrowth leads to phosphorus removal from eutrophic waters as water plants and, in particular, waterweed accumulate phosphorus in their biomass [5].

Initial studies have shown that waterweed produces a relatively high biogas yield of 415 to $520 \mathrm{~L}_{\mathrm{N}} / \mathrm{kg}_{\mathrm{VS}}$ depending on its origin [6]. Waterweed can thus be used in anaerobic digestion plants to replace a fraction of commonly used renewables such as maize or grass silage. However, the disadvantage of water plants is their high water content of $85-95 \%$. This issue complicates logistics, processing, and storage. In cold climatic regions, substrate conservation is necessary in order to guarantee year-round substrate availability. For this reason, mixed silage of waterweed with wheat straw was recently developed [7]. The advantage of using a wheat straw is its good availability and its ability to take up water from waterweed.

The aim of the research presented in this Short Communication was to test this mixed silage for its biodegradability in a long-term semi-continuous fermentation experiment. As main issues, the biogas yield and the stability of the anaerobic digestion process were investigated.

\section{Methods}

\section{Digestates and substrate}

The digestate for the semi-continuous fermentation experiment originated from an agricultural cooperative close to Grimma, Germany. The biogas plant of the agricultural cooperative has being loaded daily with $35 \mathrm{~m}^{3}$ of cattle slurry, $12 \mathrm{t}$ of maize silage, $5 \mathrm{t}$ of grass silage, and $3 \mathrm{t}$ of whole grain. The characteristics of the digestate are presented in Table 1.

The substrate for the semi-continuous fermentation process was Elodea straw silage (TS $=29.8 \% \mathrm{WW}$; VS $=85.0 \% \mathrm{TS}$ ) that was developed by the researchers at the German Biomass Research Centre (Deutsches Biomasseforschungszentrum - $\mathrm{gGmbH}$, DBFZ) in

Table 1 Characteristics of the digestate that served as an inoculum in the semi-continuous fermentation experiment

\begin{tabular}{ll}
\hline Parameter & Digestate \\
\hline $\mathrm{TS}^{\mathrm{a}}\left(\% \mathrm{WW}^{\mathrm{b}}\right)$ & 6.69 \\
$\mathrm{VS}^{\mathrm{c}}(\% \mathrm{TS})$ & 74.0 \\
$\mathrm{pH}$ & 8.29 \\
$\mathrm{NH}_{4}-\mathrm{N}(\mathrm{g} / \mathrm{L})$ & 1.70 \\
Acetate $(\mathrm{mg} / \mathrm{L})$ & 67 \\
Propionate $(\mathrm{mg} / \mathrm{L})$ & 0 \\
Butyrate $(\mathrm{mg} / \mathrm{L})$ & 0 \\
\hline
\end{tabular}

${ }^{\mathrm{a}} T S$ total solids

${ }^{\mathrm{b}} W W$ wet weight

'VS volatile solids 
Leipzig as part of the "AquaMak" project [7]. This mixed silage contained waterweed biomass (Elodea nuttallii) and chopped wheat straw with a total solids (TS) of 30\%. The plant biomass of Elodea was harvested from the river Parthe in Leipzig. Chemical silage auxiliaries based on formic acid and propionic acid were added to support the ensiling process. For ensilaging the substrate mix, lockable plastic drums and vacuum bags were used.

\section{Technical equipment}

One CSTR (continuous-stirred tank reactor) with a total volume of $40 \mathrm{~L}$ and a working volume of $31 \mathrm{~L}$ was used for the semi-continuous fermentation experiment. The motor of the stirrer (stirrer RZR 2101 control, Heidolph) was placed above the reactor. The stirrer had a rotation speed of $65 \mathrm{rpm}$. A tube in a U-form filled with distilled water was used as an overpressure and underpressure safety device. The process temperature was adjusted to $38{ }^{\circ} \mathrm{C}$ using a water-heated reactor jacket and a circulating thermostat (Integral T 1200, Lauda, Germany). The bioreactor was fitted with an insulating layer. The $\mathrm{pH}$ and temperature in the digester were measured using a combination sensor (FU20, Yokogawa Deutschland $\mathrm{GmbH}$, Germany). The biogas production was measured by a drum gas meter (TG05-PVC, Dr.-Ing. RITTER Apparatebau GmbH \& Co. KG, Germany). Online measured data, such as biogas production, temperature, and $\mathrm{pH}$, were recorded by a data logger. In order to determine the methane content in the biogas, a sample of biogas was taken from the reactor once a week using a separate sampling device at the gas measuring section.

\section{Experimental setup}

The substrate was supplied to the fermenters once a day, 7 days a week. After an adjustment period (AP) of 7 days at an organic loading rate (OLR) of $0.5 \mathrm{~kg}_{\mathrm{vS}} /(\mathrm{L} * \mathrm{~d})$, the ORL was adjusted as described in Table 2. The hydraulic retention time (HRT) was adjusted by adding tap water to the feeding substrate in accordance with Table 2. The reason for the shortening of HRT in period III of the fermentation was to enable agitation after the increase of the OLR to $3 \mathrm{~kg}_{\mathrm{vS}} /\left(\mathrm{L}^{*} \mathrm{~d}\right)$. In order to support the $\mathrm{AD}$ process and ensure a defined substrate composition, a nitrogen source, 66.4 g of urea, was added on day 183.

Table 2 Operational conditions during semi-continuous fermentation

\begin{tabular}{llll}
\hline Period & $\begin{array}{l}\text { Time } \\
{[\mathrm{d}]}\end{array}$ & $\begin{array}{l}\text { Organic loading rate }(\mathrm{OLR}), \\
{\left[\mathrm{kg} v \mathrm{~s} /\left(\mathrm{L}^{*} \mathrm{~d}\right)\right]}\end{array}$ & $\begin{array}{l}\text { Hydraulic retention time } \\
(\mathrm{HRT}),(\mathrm{d})\end{array}$ \\
\hline AP & $0-7$ & 0.5 & 100 \\
I & $8-34$ & 1.0 & 100 \\
II & $35-133$ & 2.0 & 100 \\
III & $134-212$ & 3.0 & 30 \\
\hline
\end{tabular}

Samples of digestate were taken twice a week and analyzed as described below. The experiment lasted 212 days.

\section{Analyses}

The samples of digestates were analyzed directly after sampling. The methods used for the analyses are summarized in Table 3. TS and volatile solids (VS) were measured in the original samples without pre-treatment. The samples were passed through a sieve with a mesh size of $0.75 \mathrm{~mm}$. The sieved sample was centrifuged for $10 \mathrm{~min}$ at $5.300 \mathrm{rpm}$ (Heraeus-Labofuge 200, Thermo Fisher Scientific GmbH, Dreieich, Germany) and filtered afterwards (SM 16249 pressure filtration device, Sartorius, Göttingen, Germany; nylon membrane filter: pore size $0.45 \mu \mathrm{m}$, Whatman, Germany) and analyzed for ammonium-nitrogen $\left(\mathrm{NH}_{4}-\mathrm{N}\right)$ and the volatile fatty acids (VFA) acetate, butyrate, and propionate.

Once a week, a $20 \mathrm{~mL}$ sample of biogas was taken, and its biogas composition (methane, hydrogen, nitrogen, and oxygen percentages) was determined by means of gas chromatography using an Agilent GC 6850 WLD wavelength detector (Agilent Technologies, USA) and an HP Plot separation column as well as argon as the carrier gas. A gas mixture of $49.8 \%$ methane and $50.2 \%$ nitrogen was used as the calibration gas.

\section{Results and discussion}

The time profiles of daily biogas production and volatile fatty acids are presented in Fig. 1.

During period I with an OLR of $1 \mathrm{~g}_{\mathrm{VS}} /(\mathrm{L} * \mathrm{~d})$, the methane concentration in the biogas was $49.6 \pm 2.7 \%$, and the specific biogas yield was $452 \pm 43 \mathrm{~mL}_{\mathrm{N}} /\left(\mathrm{g}_{\mathrm{Vs}}{ }^{*} \mathrm{~d}\right)$ on average. The acetate concentration rose during the first 2 weeks to values of about $2000 \mathrm{mg} / \mathrm{L}$ in an almost linear manner. However, over the further course of the experiment, the acetate concentration stabilized at values below $500 \mathrm{mg} / \mathrm{L}$ (Fig. 1). During period II with an OLR of $2 \mathrm{gvs}_{\mathrm{VS}} /(\mathrm{L} * \mathrm{~d})$, the specific biogas yield first dropped to one third of its initial value, but over a period of 2 weeks, the specific biogas yield (SBY) returned to its value before the OLR increase. The SBY was $478 \pm 84 \mathrm{~mL}_{\mathrm{N}} /$ $\left(\mathrm{g}_{\mathrm{VS}}{ }^{*} \mathrm{~d}\right)$ in the second phase (II); the methane content in the biogas was $50.6 \pm 3.7 \%$. During period III, the methane concentration in the biogas was $51.2 \pm 14.5 \%$, and the average specific biogas yield was $505 \pm 40 \mathrm{~mL}_{\mathrm{N}} /$ $\left(g_{v s}{ }^{*} d\right)$. This means that the average specific methane yield (SMY) was found to be as high as approximately $259 \mathrm{~mL}_{\mathrm{CH} 4} /\left(\mathrm{g}_{\mathrm{VS}}{ }^{*} \mathrm{~d}\right)$ on average, which confirms the results of Gallegos et al. [7], who determined the methane potential for the substrate used here in fermentation batch tests. According to their results, $231 \pm 5 \mathrm{~mL}_{\mathrm{CH} 4} /$ $\mathrm{g}_{\mathrm{vs}}$ was produced from Elodea straw silage. Furthermore, the SMY is as high as the SMY of rye grass silage 
Table 3 Parameters and analytical methods for the evaluation of the digestate

\begin{tabular}{|c|c|c|}
\hline Parameter & $\begin{array}{l}\text { Sample } \\
\text { pre-treatment }\end{array}$ & Analytical methods \\
\hline TS & None & DIN 12880 \\
\hline VS & None & DIN 12879 \\
\hline VFA/TAC & Sieved & $\begin{array}{l}\text { Titration method according to Lili et al. [13], Burete Digital BRAND, Microprocessor pH-Meter pH } 95 \text { (WTW, } \\
\text { Weilheim, Germany) }\end{array}$ \\
\hline $\mathrm{NH}_{4}-\mathrm{N}$ & Filtered & $\begin{array}{l}\text { DIN } 38406 \text { E5. Spektroquant }{ }^{\oplus} \text { test kit (measuring range } 0.01-3 \mathrm{mg} \mathrm{L}^{-1} \mathrm{NH}_{4}-\mathrm{N} \text {, Merck, Germany), photometric } \\
\text { measurement with MultiLab P5 (WTW, Weilheim, Germany) }\end{array}$ \\
\hline $\begin{array}{l}\text { Acetate, propionate, } \\
\text { butyrate }\end{array}$ & Filtered & HPLC (Shimadzu, Japan); detector: RID-10A; column: VA 300/7.8 Nucleogel lon 300 OA; eluent $0.05 \mathrm{M} \mathrm{H}_{2} \mathrm{SO}_{4}$ \\
\hline $\begin{array}{l}\text { Water-soluble } \\
\text { elements }\end{array}$ & Filtered & Inductively coupled plasma atomic emission spectrometry ICP-AES (Spectroflame, Spectro Int., Kleve, Germany \\
\hline
\end{tabular}

(249-399 $\mathrm{mL}_{\mathrm{CH} 4} /\left(\mathrm{g}_{\mathrm{VS}}{ }^{*} \mathrm{~d}\right)$ [8]) or of swine manure $\left(240 \mathrm{~mL}_{\mathrm{CH} 4} /\left(\mathrm{g}_{\mathrm{Vs}} * \mathrm{~d}\right)\right.$ [9]). Pure straw silages reach SMYs of $180-300 \mathrm{~mL} /\left(\mathrm{g}_{\mathrm{VS}}{ }^{*} \mathrm{~d}\right)$ [10]. The concentrations of volatile fatty acids rose very quickly after the increase of the OLR to $3 \mathrm{~g}_{\mathrm{VS}} /(\mathrm{L} * \mathrm{~d})$. The propionate concentration achieved a value of $2500 \mathrm{mg} / \mathrm{L}$; the acetate concentration was $1700 \mathrm{mg} / \mathrm{L}$, and the butyrate concentration reached its maximum of $92 \mathrm{mg} / \mathrm{L}$. Over-acidification led to a decrease in biogas production, and as a result, the experiment was stopped after 212 test days. Kampmann et al. [11] described for an AD experiment that an overacidification of the digestate was accompanied by an increasing OLR amount of maize silage right up to overloading. Therefore, the optimum OLR for the Elodea straw silage substrate was achieved at $2 \mathrm{~g}_{\mathrm{VS}} /(\mathrm{L} * \mathrm{~d})$ in the case described here where no acidification of the digestate was observed during this period.

The ammonium-nitrogen concentration was approximately $2000 \mathrm{mg} / \mathrm{L}$ at the beginning and dropped to a critical concentration of $500 \mathrm{mg} / \mathrm{L}$ on day 183 . After the addition of urea, the ammonium-nitrogen concentration rose to $1200 \mathrm{mg} / \mathrm{L}$ again and remained above $800 \mathrm{mg} / \mathrm{L}$ until the end of the fermentation experiment. No trace element additives had to be added.

The volatile fatty acid (VFA)/Alkalinity, buffer capacity (TAC) ratio and the $\mathrm{pH}$ value are shown in Fig. 2. The $\mathrm{pH}$ was stable in the range of $8.0 \pm 0.2$ in the first (I) and second (II) periods of the fermentation experiment. Thus, the optimum for methanogenic archaea was maintained, and the required $\mathrm{pH}$ conditions for the biogas process of $\mathrm{pH}=6.5$ to 8.1 according to Graf [12] were ensured. After the addition of urea on day 183, the $\mathrm{pH}$ value rose to 8.25 for a short period. At the end of the experiment after period III, the $\mathrm{pH}$ dropped to 7.4 due to over-acidification of the digestate.

The condition of the biogas process in the fermenter can be quickly assessed using the VFA/TAC ratio [13]. If the ratio of volatile fatty acids (VFA) to the total inorganic carbonate buffer (TAC) exceeds a critical value (0.4), the process must be assumed to be overloaded

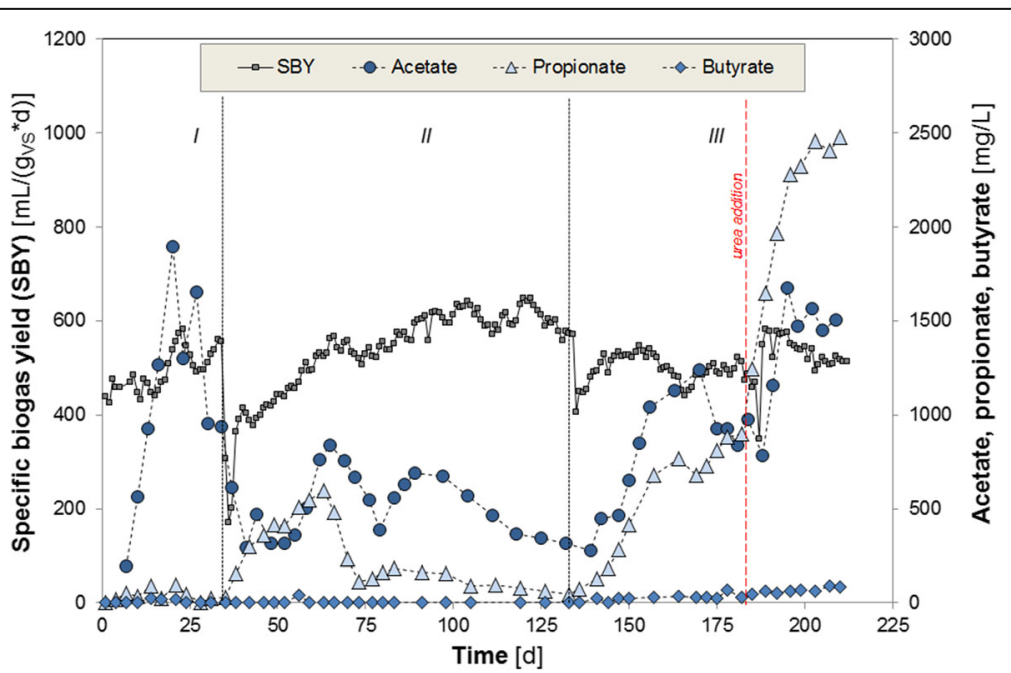

Fig. 1 Specific biogas yield and volatile fatty acid concentrations (acetate, propionate, and butyrate) during the fermentation experiment using Elodea straw silage as mono-substrate 


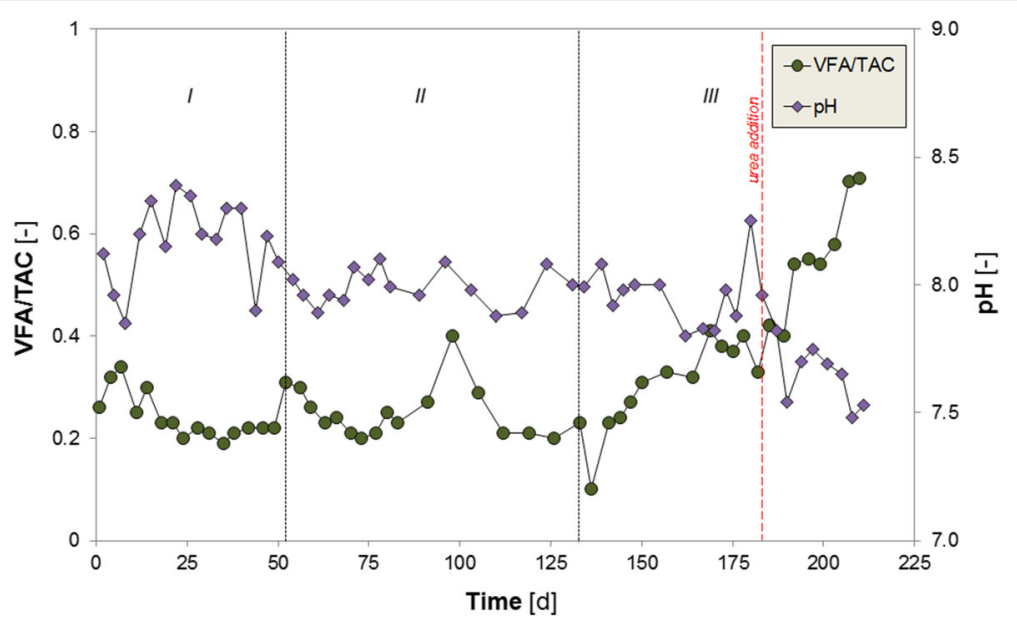

Fig. 2 VFATAC and pH value over the course of semi-continuous fermentation using Elodea straw silage as mono-substrate
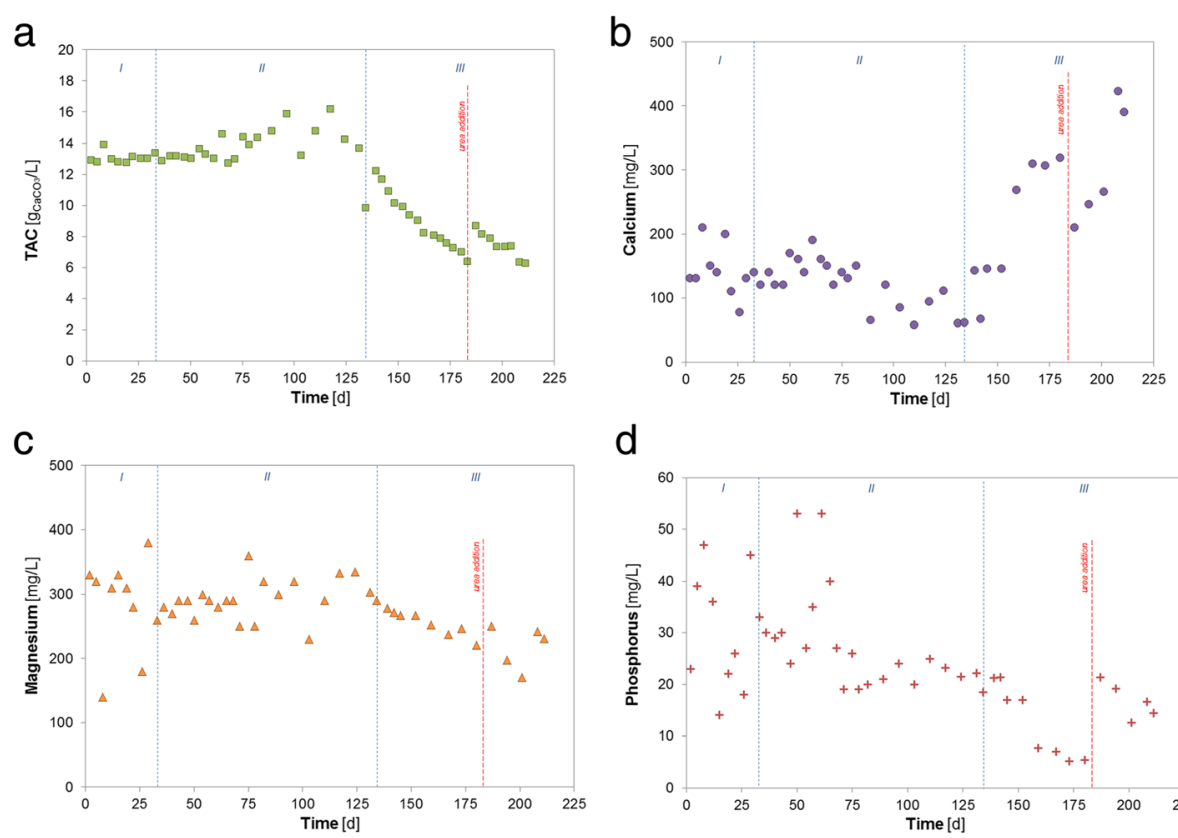

d
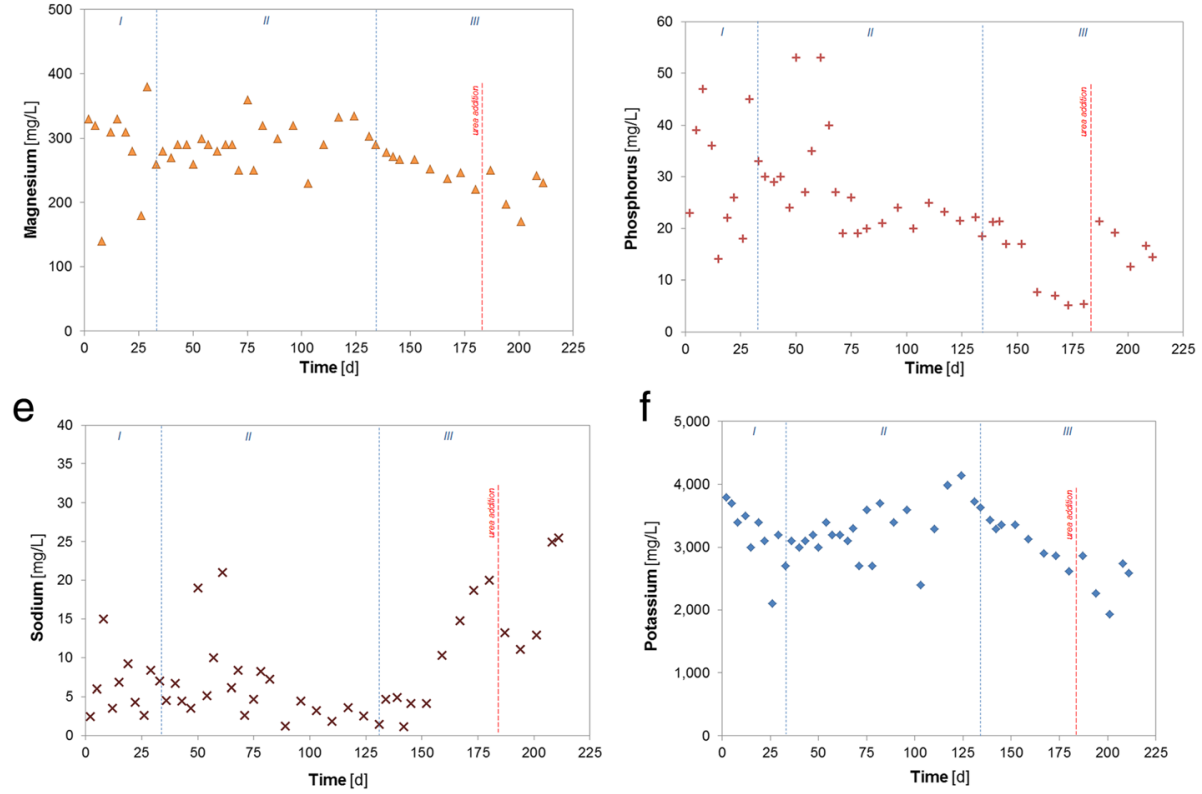

Fig. 3 Buffer capacity (TAC) and concentrations of water-soluble elements. Buffer capacity (a), concentrations of calcium (b), magnesium (c), phosphorus (d), sodium (e) and potassium (f) in the course of semi-continuous fermentation using Elodea straw silage as mono-substrate 
[9, 14]. Despite the increased acetate concentration during period I, the VFA/TAC ratio remained stable at $0.25 \pm 0.05$. The critical VFA/TAC ratio of 0.4 was transcended only in period III (from 0.23 at the beginning to 0.76 at the end of period III), caused by the increase in the substrate input, while the buffer capacity decreased from $13.6 \pm 0.9$ (mean value of TAC during periods I and II) to $6.3 \mathrm{~g}_{\mathrm{CaCO} 3} / \mathrm{L}$ on day 211 (Fig. 3a). The increase in the VFA/TAC ratio despite decreasing TAC values was caused by a strong increase of VFA from $3.3 \pm 0.8 \mathrm{~g} / \mathrm{L}$ (mean value of VFA during periods I and II) to $4.8 \mathrm{~g} / \mathrm{L}$ on day 211. After increasing the OLR to $3 \mathrm{~g}_{\mathrm{VS}} /\left(\mathrm{L}^{*} \mathrm{~d}\right)$, the VFA/ TAC ratio increased slowly up to a value of 0.58 in parallel with the steady increase of the acetate and propionate concentrations. Both VFA/TAC and $\mathrm{pH}$ reflect the situations immediately after the increase of the OLR in period III and can therefore be explained by the adaptation of the microorganisms to the increased substrate addition.

The concentrations of water-soluble elements (Fig. 3b-f) were mostly stable during the first two periods of the experiment. Nevertheless, as in the case of TAC (Fig. 3a), the concentrations of these elements changed rapidly. The magnesium (Fig. 3c), phosphorus (Fig. 3d), and potassium (Fig. 3f) concentrations fell, whereas the concentrations of calcium (Fig. 3b) and sodium (Fig. 3e) displayed an upward trends. After the addition of urea on day 183, these tendencies were reversed for 14 days before returning back thereafter. This effect was due to the $\mathrm{pH}$ shift in the water phase caused by the urea addition, as can be seen in Fig. 2 .

The results showed that the mono-digestion of the Elodea wheat straw silage is possible. However, it was necessary to add a nitrogen source in order to prevent a process failure. For this experiment, urea was chosen as a nitrogen source as it is a well-defined substance. For the practice, co-digestion using co-substrates high in nitrogen such as poultry manure [15] has to be taken into account.

\section{Conclusions}

The results of this semi-continuous fermentation experiment confirm the digestibility of Elodea straw silage in the biogas process in a long-term experiment which was the aim of this Short Communication. It was shown that mono-fermentation of the given substrate was stable for a time period of at least 6 months. The maximum OLR in the fermentation experiment was found to be as high as $3 \mathrm{~g}_{\mathrm{VS}} /(\mathrm{L} * \mathrm{~d})$. Nevertheless, at this OLR, the digestate in the fermenter became too viscous, resulting in clogging and insufficient mixing and this lead to overacidification. Thus, the most stable results were achieved at an OLR of $2 \mathrm{~g}_{\mathrm{VS}} /(\mathrm{L} * \mathrm{~d})$, when the highest specific biogas yield of $642 \mathrm{~mL}_{\mathrm{N}} /\left(\mathrm{g}_{\mathrm{VS}}{ }^{*} \mathrm{~d}\right)$ was reached. Further experiments are needed in order to evaluate the behavior of the Elodea straw silage in non-continuously stirred systems, which are common in practice.

\section{Additional file}

Additional file 1: Process parameters during the semi-continouous

fermentation. (PDF $216 \mathrm{~kb}$ )

\section{Abbreviations}

AD: Anaerobic digestion; AP: Adjustment period; FM: Fresh mass; HRT: Hydraulic retention time [d]; OLR: Organic loading rate $\left[g_{v s} /\left(L^{*} d\right)\right]$; SBY: Specific biogas yield $\left[\mathrm{mL} /\left(\mathrm{gvs}^{*} \mathrm{~d}\right)\right]$; SMY: Specific methane yield $[\mathrm{mL} /$ (gvs $\left.{ }^{*} \mathrm{~d}\right)$ ]; TAC: Alkalinity, buffer capacity; TS: Total solids [\% WW]; VFA: Volatile fatty acids [g/L]; VS: Volatile solids [\% TS]; WW: Wet weight

\section{Acknowledgements}

The authors would like to thank Sophia Probst for her support in analyzing the samples and carrying out the experiment and Grit Weichert for her support in the Centre for Environmental Biotechnology's laboratory.

\section{Funding}

The investigations that form the basis for this article were carried out within the framework of the "Aquatic macrophytes-Optimal ecological and economic use" (AquaMak) research project. The "AquaMak" project is supported by the German Federal Ministry of Food, Agriculture and Consumer Protection with funds from the so-called "Energy and Climate Funds (EKF)" on the basis of a decision of the German Parliament (grant number: 22403013). The project partners are the Helmholtz Centre for Environmental Research-UFZ, Nürtingen-Geislingen University-HfWU, and the German Biomass Research Centre-DBFZ.

\section{Availability of data and materials}

The datasets supporting the conclusions of this article are given in Additional file 1.

\section{Authors' contributions}

$A B$ analyzed the fermentation samples during the $A D$ experiment and wrote the manuscript. $L M$ designed the AD experiment and wrote the manuscript. HW and WS provided the Elodea straw silage and read the manuscript and contributed with consultations. AZ headed the project, collected and sorted the publication and information material, and prepared the manuscript. All authors edited and approved the final manuscript.

\section{Authors' information}

$A B$ and $L M$ are researchers at the Centre for Environmental Biotechnology at the Helmholtz Centre for Environmental Research GmbH-UFZ. HW and WS are researchers in the department of Biochemical Conversion at the German Biomass Research Centre-DBFZ. AZ is a senior researcher and group leader of the Bioprocess Engineering research group at the Centre for

Environmental Biotechnology at the Helmholtz Centre for Environmental Research GmbH_-UFZ_-and a Professor at the University of Cooperative Education Riesa.

Ethics approval and consent to participate Not applicable

\section{Consent for publication}

Not applicable

\section{Competing interests}

The authors declare that they have no competing interests.

\section{Publisher's Note}

Springer Nature remains neutral with regard to jurisdictional claims in published maps and institutional affiliations. 


\section{Author details}

'Helmholtz Centre for Environmental Research -UFZ, Centre for Environmental Biotechnology, Permoserstrasse 15, 04318 Leipzig, Germany. ${ }^{2}$ German Biomass Research Centre_DBFZ, Torgauer Strasse 116, 04347

Leipzig, Germany.

Received: 20 September 2017 Accepted: 22 December 2017

Published online: 05 February 2018

\section{References}

1. Rönicke H (2008) Jahreszeitliche Entwicklung und Nährstoffversorgung submerser Makrophyten im Tagebau Goitsche. Proceedings of 1st Conference on Elodea nuttallii in Goitzsche lake 2008. Brehna, LK Anhalt Bitterfeld, pp 1-14

2. Zehnsdorf A, Hussner A, Eismann F, Rönicke H, Melzer A (2015) Management options of invasive Elodea nuttallii and Elodea canadensis. Limnologica 51:110-117. https://doi.org/10.1016/.limno.2014.12.010

3. Zerbe S, Wiegleb V (2008) Renaturierung von Ökosystemen in Mitteleuropa. Spektrum

4. Hussner A, Stiers I, Verhofstad MJJM, Bakker ES, Grutters BMC, Haury J, van Valkenburg JLCH, Brundu G, Newman J, Clayton JS, Anderson LWJ, Hofstra D (2017) Management and control methods of invasive alien aquatic plants: a review. Aquat Bot 136:113-137. https://doi.org/10.1016/j.aquabot.2016.08. 002

5. Robach F, Hajnsek I, Eglin I, Trémolières M (1995) Phosphorous sources for aquatic macrophytes in running waters: water or sediment? Acta Bot Gallica 142:719-731 ISSN 1253-8078

6. Zehnsdorf A, Korn U, Pröter J, Naumann D, Seirig M, Rönicke H, Pieper B (2011) Western waterweed (Elodea nuttallii) as a co-substrate for biogas plants. Agric Eng 66:136-139

7. Gallegos D, Wedwitschka H, Moeller L, Zehnsdorf A, Stinner W (2017) Effect of particle size reduction and ensiling fermentation on biogas formation and silage quality of wheat straw. Bioresour Technol 245:216-224. https:// doi.org/10.1016/j.biortech.2017.08.137

8. Vitěz $T$, Koutný $T$, Geršl $M$, Kudělka J, Nitayapat $N$, Ryent $P$, Hejduk $S$, Lošák T, Vítězová M, Mareček J (2015) Biogas and methane yield form rye grass. Acta Universitatis Agriculturae et Silviculturae Mendelianae Brunensis, 63(1):143-146. https://doi.org/10.11118/actaun201563010143

9. Eder B, Schulz H (2006) Substrate. In: Eder B, Schulz H (eds) Biogas Praxis, Grundlagen, Planung, Anlagenbau, Beispiele, Wirtschaftlichkeit, 4th edn. Ökobuch Verlag, Staufen bei Freiburg, pp 41-69

10. Bischofsberger, W, Dichtl, N, Rosenwinkel, K H, Seyfried, C F, Böhnke, B (2005) Anaerobtechnik. Springer-Verlag, Berlin-Heidelberg

11. Kampmann K, Ratering S, Geißler-Plaum R, Schmidt M, Zerr W, Schnell S (2014) Changes of the microbial population structure in an overloaded fed-batch biogas reactor digesting maize silage. Bioresour Technol 174: 108-117

12. Graf W (1999) Kraftwerk Wiese: Strom und Wärme aus Gras. BoD-Books on Demand

13. Lili M, Biró G, Sulyok E, Petis M, Borbély J, Tamás J (2011) Novel approach on the basis of FOS/TAC method. Analele Universității din Oradea, Fascicula: Protectia Mediului 17:713-718, http://protmed.uoradea.ro/facultate/anale/ protectia_mediului/2011B/im/15.\%20Mezes\%20Lili.pdf

14. Watter H (2015) Regenerative Energiesysteme: Grundlagen, Systemtechnik und Analysen ausgeführter Beispiele nachhaltiger Energiesysteme. SpringerVerlag, Wiesbaden

15. Böjti T, Kovács KL, Kakuk B, Wirth R, Rákhely G, Bagi Z (2017) Pretreatment of poultry manure for efficient biogas production as monosubstrate or co-fermentation with maize silage and corn stover. Anaerobe 46:138-145 ISSN 1075-9964

\section{Submit your manuscript to a SpringerOpen ${ }^{\circ}$ journal and benefit from:}

- Convenient online submission

- Rigorous peer review

- Open access: articles freely available online

- High visibility within the field

- Retaining the copyright to your article 